Vol. 5 No. 1, January 2021, pp. 22-40

\title{
Identifying Social Contexts Upon The Annual Homecoming Prohibition Due to The Covid-19 Outbreak
}

\author{
Kukuh Fadli Prasetyo* \\ Faculty of Law, YARSI University, Jakarta - Indonesia
}

\begin{abstract}
Despite its well-established value, the 1441 AH annual homecoming was prohibited by the Government of Indonesia to halt the COVID-19 outbreak. This paper aims to illustrate as well as analyse social factors that come up along with the implementation of the regulation. This research employs the so-called socio-legal research method. The intercourse between law and society has been discussed thoroughly. Later, the discussion builds a connection between law and society in which law initiates changes within society. Furthermore, as this regulation intends to adjust a well-established social value, this paper offers analysis from a perspective of sociology of law. There is a list of considerations to study. First, the legitimate lawmakers and the measurable benchmark are the main sociological strength of the law. Secondly, the absence of an integrated punishment and the ad-hoc basis of policy-making reduce the capacity to create social changes. Besides, other social factors ignored by the Government range from the recognition of this annual homecoming as social value to the ignorance of current social solidarity in Indonesia.
\end{abstract}

Keywords: Social change; Homecoming: COVID-19 Pandemic; Indonesia.

\section{INTRODUCTION}

The Corona Virus Disease 2019 (COVID-19) pandemic caused a catastrophic situation in Indonesia. Many people are infected, including those who eventually died. The government, in responding to this pandemic, established Government Regulation No. 21 of 2020 on Large-scale Social Restriction in the Effort to Handle COVID-19. A crucial point of the regulation is the delegation of authority to the local government in applying a large-scale social restriction policy as long as approved by the national government, represented by the Minister of Health. ${ }^{1}$

The local authorities took an effect on government regulation in the regions by emphasizing a physical (or social) distancing that requires people to keep in a safe distance among others. In practice, they regularly warn the peoples to avoid a crowd.

The limitation of the transportation sector ${ }^{2}$ is one of the government's concerns to prevent the spread of the pandemic extensively. Basically, the local government restricts the movement of people and goods. In the Special

\footnotetext{
*Email/Corresponding Author: kukuh.fadli@yarsi.ac.id / prasetyo.kf@gmail.com

${ }^{1}$ Government Regulation No. 21 of 2020 concerning Large-scale Social Restriction in the Effort to Handle COVID-19, Art. 2.

${ }^{2}$ Regulation of Minister of Health No.9 of 2020 concerning Guidelines of Large-scale Social Restriction, Art. 13 (1e)
} 
Capital Region of Jakarta, for example, a policy was adopted during the large-scale social restriction to reduce the operation of superstructure and infrastructure of some mass transportations, such as the service termination of two mass rapid transit (MRT) stations. ${ }^{3}$ A sharp decline in public transportation passengers was a consequence of the policy. ${ }^{4}$

A transportation policy was quite shocking to the public when the Regulation of Minister of Transportation No. 25 of 2020 concerning Transportation Control During the 1441 AH Annual Homecoming (hereinafter, Transportation Minister Regulation on Mudik Control) impose a temporary ban to peoples' activity for carrying out an annual homecoming, or popularly called 'mudik'. ${ }^{5}$ The regulation made clear a public discourse regarding the need to prohibit or not peoples to visit their hometown, which has been annually practiced for decades in Indonesia.

The government seriously acknowledged this domestic travel ban to the public. In order to deliver the importance of this policy, the President himself officially announced the prohibition of annual homecoming. Besides, he also offered some alternatives to suggest the people to not exodus before eid. ${ }^{6}$ Despite a criticism that the prohibition would lead to an economic stagnancy following the limited transport operators' activities, the government consistently bans mudik for workers. ${ }^{7}$

There has been estimated at least 1.3 million people who work in the regions of Jakarta, Bogor, Depok, Tangerang, and Bekasi return to their hometown in April 2020.8 Some of them have not obeyed the bans, intentionally return to their hometown by using various means. As an example, police officers found some persons hiding in a mixer truck. ${ }^{9}$ This indicates that the policy cannot be effectively applied as many peoples still keep visiting their hometowns.

The bans for mudik in 2020 are not the first time applied in Indonesia. History reveals two situations that restricted the mudik. The first ban was imposed in 1946. Most Muslims were not able to celebrate the Eid al Fitr due to the numerous armed conflict between the Indonesian armed forces and

\footnotetext{
Tempo

(a),"MRT

Jakarta

Closes

Two More

Stations", https://en.tempo.co/read/1334459/mrt-jakarta-closes-two-more-stations.

4 Jakarta Post (a), "Public Transportation Use in Greater Jakarta Plummets during Pandemic: BPTJ", https://www.thejakartapost.com/news/2020/04/20/publictransportation-use-in-greater-jakarta-plummets-during-covid-19-pandemic-bptj.html.

5 Regulation of Minister of Transportation No.25 of 2020 concerning Transportation Control During the 1441 AH Annual Homecoming, Art. 1.

6 Cabinet Secretariat of Republic of Indonesia,"Gov't Revises National Holiday, Collective Leave 2020", https://setkab.go.id/en/govt-revises-national-holiday-collectiveleave-2020/

7 Jakarta Post (b), "Government to Allow Public Transportation to Operate but Still bans 'Mudik", https://www.thejakartapost.com/news/2020/05/06/government-to-allowpublic-transportation-to-operate-but-still-bans-mudik.html.

8 CNBC Indonesia, "Ada Corona, 1,3 Juta Orang Tetap Ngotot Mudik di Jabodetabek, https://www.cnbcindonesia.com/news/20200414125207-4-151775/adacorona-13-juta-orang-tetap-ngotot-mudik-di-jabodetabek

9 Tempo (b), "Polisi Sebut Ada Orang yang Ngumpet di Truk Molen agar Bisa Mudik", https://nasional.tempo.co/read/1339435/polisi-sebut-ada-orang-yang-ngumpetdi-truk-molen-agar-bisa-mudik
} 
Koningklijk Nederlandsh-Indies Leger (KNIL - the Royal Netherlands-Indies Army) that occurred in some regions, including Bogor. Some urban workers were then restricted to return to their hometowns. ${ }^{10}$ The second ban was imposed in the 1960-s during the political efforts to take West Papua back to the Republic of Indonesia. The government at that time warned people to restrictively use transportation in order to support the fundraising agenda and to secure the state budget. The ban was partially effective because the limitations were only applied to the Jakarta railways service, while other cities, such as Yogyakarta, provide normal service to the people. ${ }^{11}$

As described by Agus Maladi Irianto, mudik covers numerous dimensions. The first is the spiritual aspect which drives people to visit their predecessor as well as remind them about the next stage of their life. Secondly, it also puts a psychological dimension in which they can escape from their stressful days at their workplace. The third aspect is social consideration which enables the migrant workers to tell their family and relatives their inspiring story. The last point mentions their pride in being an outstanding social member. ${ }^{12}$

The bans of mudik policy cannot only be seen from a legal perspective, primarily with regards to many violations to the regulation by some peoples. It should also be viewed as an issue of social engineering, as it concerns a direction to change the society's mindset and behaviour. Steven Vago's three characteristics of social change 13 may describe this situation. First, the annual homecoming ban would change people's behaviour on a massive scale. The law, therefore, would not only affect the urban workers, but also their family and relatives who live in the hometown/villages. Second, social change also modifies the way of people interact with others as the urban workers and their family's lives in their hometowns can not conduct collective activities as they cannot meet up on the Eid al Fitr moment. Third, the change of group activities to which numerous people are engaging drives a broader change in the way each person relates to others.

In the large-scale bureaucratic society, Yehezkel Dror opines that social changes should be addressed and organised by the law. He also argues that "if the state desires to set up a public body the function of which bringing about certain social changes, it is necessary to use the law to set up the body and define its powers". ${ }^{14}$ Additionally, concerning the social obstacles to enforce the mudik ban, the government should also take into account the way those legal instruments deal with the social barriers.

This paper aims to analyze the social contexts which influence the efficacy of the implementation of the temporary homecoming (mudik) ban

10 Historia (a), "Lebaran tanpa Mudik di Awal Republik", https://historia.id/militer/articles/lebaran-tanpa-mudik-di-awal-republik-vXlOr.

11 Historia (b), "Mudik Tahun 1960-an", https://historia.id/urban/articles/mudiktahun-1960-an-6k4pR.

12 Agus Maladi Irianto, "Mudik dan Keretakan Budaya", Humanika 15, no. 2 (2012)

13 Steven Vago, Law and Society (New Jersey: Prentice -Hall, Inc., 1991), 214-215.

14 Yehezkel Dror, "Law and Social Change", in Sociology of Law: Selected Readings, edited by Vilhelm Aubert (New York: Penguin Books Ltd., 1977), 94. 
policy. It is expected to contextualise the social contents into the sociological rationale in the lawmaking process.

It is a socio-legal research that uses social contexts in a legal research and builds a contextual bridge between facts and values. ${ }^{15}$ It collects primary, secondary, and tertiary legal sources and resources to support the analysis. Most studies on Indonesian annual homecoming are analysed from the perspective of sociology. ${ }^{16}$ Otherwise, this research offers a legal perspective to analyse this social phenomenon.

\section{RESULT AND ANALYSIS}

\subsection{Law and Social Change}

\subsubsection{Intercourses between Law and Social Change}

For decades, the reciprocity between law and society has raised attention from numerous scholars. Social change can affect a change in legal substances. It covers a paradigm that social changes must be followed by legal reform. Conversely, the law can also lead to social changes. This puts law as a determinant to change society. ${ }^{17}$

Primarily, the historical school of jurisprudence fought the idea of society changed by law, as its supporters assumed that law is formed by social value. As cited by Dror, Von Savigny, the founder of this school, proposed a concept of volksgeist (spirit of the nation) regarded law as an organic indigenous to each society. ${ }^{18}$ It means that law is formed by society, not by any source outside the society.

L.J. van Apeldoorn resists Savigny's thought and argues that the historical assumption was only relevant to prehistoric societies. He additionally states that the more civilised the society is, the more heterogeneous its member will be. It drives a more complex society in which the division of labour becomes more complicated. In the long term, it would give birth to a new social class, the jurists. ${ }^{19}$

This new class, generally representing people as whole, rapidly develops the law to which non-jurist citizens would no longer pay

15 This reflects the notions of socio-legal scholars, such as Roscoe Pond and Oliver Wendell Holmes Jr: "law in the books and blackletter law is important but not enough to understand how 'law' develops, what it does and does not to society, how it can be made (more) effctive and - sometimes - less harmful?". Frans L. Leeuw, "Empirical Legal Research: The Gap between Facts and Values and Legal Academic Training", Utrecht Law Review 11, no. 2 (2015): 23.

16 See Irianto, op.cit. See also Muskinul Fuad, "Makna Hidup di Balik Tradisi Lebaran", Komunika 5, no. 1 (2011): 111.

17 Vago, op.cit., 216.

18 Dror, op.cit., 92.

19 L.J. van Apeldoorn, Pengantar Ilmu Hukum [Inleiding tot de Studie van het Nederlandsche Recht], translated by Oetarid Sadino, (Jakarta: Pradnya Paramita, 2011), 130. 
attention. ${ }^{20}$ For instance, a taxi driver knows the law on transportation only, but he does not have any interest in the law relating to the capital market.

In modern ages, the government plays a formal role to arrange social life. By performing its law-making powers, the government can enact a regulation to initiate social change. Due to its written form, Soerjono Soekanto idealises that law is able to produce a planned social change, not a planless change. ${ }^{21}$

One of the outstanding social changes enforced by law is that, in the 1960s, American law has been used as the preeminent instruments to improve social and political positions of African American citizens. ${ }^{22}$ According to the statistics provided by the United States Department of Education, this law removed racial barriers to education. ${ }^{23}$

Soekanto, further, says that law can either directly or indirectly organise social changes. ${ }^{24}$ Similarly, Dror also distinguishes those approaches. On one hand, law indirectly changes society by establishing social institutions by which society would be affected directly. On the other hand, the direct role of law enables the law to interact with basic social institutions in a manner of constituting a direct relationship between law and social change. ${ }^{25}$

In line with Dror's approach, Bernard Arief Sidharta is in the opinion that, between two approaches, the application of a new set of rules in a framework of direct change is rather difficult instead of the indirect change. Although its original intent benefits society, this policy cannot be directly understood by the people. Therefore, Sidharta suggests the government allocate more resources and more legal officers to support the law as a tool of social engineering. ${ }^{26}$

\subsubsection{Advantages and Limitations of Law to Produce Social Change}

Promisingly, a social change designed by law would be systematically organised by the public authorities. Howbeit, the extent to which law can bring about social changes varies according to the conditions in each circumstance. ${ }^{27}$ It, of course, stands on the advantages and disadvantages of law to create social changes. Briefly, Steven Vago considers numerous advantages of law in creating social change.

\section{Ibid.}

21 Soerjono Soekanto (a), Pokok-pokok Sosiologi Hukum (Jakarta: PT RajaGrafindo Persada, 2006), 122.

22 Vago, op.cit., 220.

23 United States Department of Education, "Impact of the Civil Rights Laws", https://www2.ed.gov/about/offices/list/ocr/docs/impact.html.

${ }^{24}$ Ibid.

25 Dror, op.cit., 93.

26 Bernard Arief Sidharta, Refleksi tentang Struktur Ilmu Hukum: Sebuah Penelitian tentang Fundasi Kefilsafatan dan Sifat Keilmuan Hukum sebagai Landasan Pengembangan Ilmu Hukum Nasional (Bandung: CV Mandar Maju, 2009), 28-29.

27 Vago, op.cit., 223. 
First of all, rules must be established by a legitimate authority. This bases its obedience upon the legitimacy of the lawmakers. ${ }^{28}$ In a framework of social-political context, legitimacy discusses a question on whether an actual administration is consistent with the law. ${ }^{29}$

Secondly, the binding force of law comes from a wide range of reasons. From a democratic view, this binding force is constructed upon the assumption that law is a result of the social consensus. ${ }^{30}$ This consensus, of course, is taken from the interdependence between the government and the people. Deflem clarifies that the interdependence ${ }^{31}$ contains electoral processes (to which the public's interests are democratically represented) and legislative decision-making (in which a democratic law is established by the government and subjected to the society). ${ }^{32}$

Thirdly, the law should be equipped with legal sanctions. They, of course, make the binding force of law much more effective to order the legal subjects. ${ }^{33}$ Sanctions can be an instrument to enforce the law as well as to secure the people's obedience to the law. As described by Max Weber, law enforcement (with its sanctions) is "a special and unavoidable problem of law". 34

On the other hand, as an instrument, the law has its limitations to get involved in an effort of social change. William M. Evan, as cited by Vago, explains some conditions to what extent the law can successfully change society, as follows: 35

1. the law must emanate from an authoritative and prestigious source

2. the law must introduce its rationale in terms that are understandable and compatible with existing values;

3. the advocates of the changes should refer to other communities or countries with which the population identifies and where the law is already in effect;

4. the enforcement of the law must be aimed toward making the change in a relatively short time;

5. those enforcing the law must themselves be very much committed to the change intended by the law;

6. the implementation of the law should include positive as well as negative sanctions; and

28 Ibid., 225.

29 Brian H. Bix, A Dictionary of Legal Theory, (Oxford University Press, 2009), 126.

30 Vago, op.cit., 227.

31 Miriam Budiardjo distinguishes the relationship between the government as a ruling institution and the ruled people into two processes: interest aggregation (electoral process) and interest articulation (by which a legislation is produced). See Miriam Budiardjo, Dasar-Dasar Ilmu Politik (Jakarta: PT Gramedia Pustaka Utama, 2010), 405.

32 Mathieu Deflem, Sociology of Law: Visions of a Scholarly Tradition (New York: Cambridge University Press, 2008), 169.

33 Vago, op.cit., 229.

34 Mathieu Deflem, op.cit., 227.

35 Vago, op.cit. 223 
7. the enforcement of the law should be reasonable, not only in terms of the sanctioned use but also in the protection of rights of those who stand to lose by a violation of the law.

Likewise, Lon L. Fuller also supplies an allegory in which Rex found his failure to create his legal regime. Using a perspective of morality, he emphasises eight conditions by which law is not possible to enforce. He starts his analysis from Rex's failure to achieve rules comprehensively. This condition brought about the conflict settlements conducted on an ad-hoc basis, not on a comprehensive and systematic basis. ${ }^{36}$ Thereafter, he also condemns the concealment of the rules as the second failure. Thirdly, the failure is caused by the retroactive law that puts the subjects into a threat of retrospective change. The fourth is that the law is not understandable. The fifth failure is addressed to the establishment of a contradictory law. ${ }^{37}$ Respectively, Fuller also condemns Rex's failure to avoid frequent changes of law that "the subject cannot orient his action by them". ${ }^{38}$ The bottommost failure is that the inconsistency between the policy as enacted and the actual policy-implementation. ${ }^{39}$

It is clear that the conditions, either enabling or disabling laws to create social change, depends on how the public authorities of both policymaking and policy-implementing functions manage the advantages and limitations of law in producing social changes as briefly supplied above.

\subsection{Identifying Socio-legal Contexts: Annual Homecoming Restriction}

\subsubsection{Legitimacy of Lawmakers}

To begin with, the reason why a law was obeyed by the subjected party corresponds to the lawmakers' legitimacy. 40 In social and political discourses, legitimacy raises a question on whether the implementation is consistent with the law. ${ }^{41}$

Franz Magnis-Suseno phrases that legitimacy relates to the basis or raison d'etre of an authority. ${ }^{42}$ In the context of modern political circumstance, besides the object of authority, a study of legitimacy also looks at the legitimacy of an authorised subject. This perspective offers three types of legitimacy: (i) religious legitimacy, (ii) elite legitimacy, and (iii) democratic legitimacy. ${ }^{43}$ The religious requires that the political rights to govern must be authorised by an eternal power. The second assumed that a subject (or a party) whose special capability is comparatively outnumbered

36 Lon F. Fuller, The Morality of Law (New Haven: Yale University Press, 1969), 39

37 Ibid.

38 Ibid.

39 Ibid.

40 Vago, op.cit., 225.

41 Bix, loc.cit..

42 Franz Magnis-Suseno, Etika Politik: Prinsip Moral Dasar Kenegaraan Modern (Jakarta: PT Gramedia Pustaka Utama, 2016), 63.

43 Ibid., 65 
the others has a right to govern the society. Thirdly, democratic legitimacy stands upon the mechanisms representing the sovereignty of people. ${ }^{44}$

The rules regarding the annual homecoming prohibition and, in a broader sense, the implementation of large-scale social restriction is conducted by the executive branch. Despite the absence of legislative bodies, the rule-making process is still conducted by a legitimate officer, the President as the head of the executive ${ }^{45}$.

Besides its legality, in the Indonesian political order, the government also has its non-legal legitimacy. In a presidential system, the pair of president and Vice-president is politically legitimate, because he is directly elected by the people. ${ }^{46}$ Here, the majority of people vote as well as give the elected their collective rights to which the elected and his cabinet govern. Due to that understanding, the executive enacting its regulation can determine the rule to which the people ought to respect.

\subsubsection{Benchmark of Best-Practices}

Best practices are usually taken into consideration by the Government of Indonesia in a decision-making process. It represents the willingness of the government to produce social change which is designed by legal instruments. ${ }^{47}$ Of course, the government would like to simply deliver the successful approaches used by other countries.

Although some people demanded a lockdown to localise the outbreak of COVID-19, the executives refused to impose it due to its potential losses. For example, in India, the announcement of a nation-wide lockdown led people to start huge transportation across this South Asian country. It also brought about a rapid increase in the number of jobless. Moreover, Al Jazeera reported that the stress of lockdown overtook the stress of the disease. ${ }^{48}$

The government also considers the effectiveness of lockdown to halt the spread of the disease. In Italy, the adoption of lockdown to which criminal sanctions were attributed was not followed by the decrease in cases of infection. Moreover, while applying this policy, their cases of deaths outstripped China. ${ }^{49}$

In comparison, the administration admitted the flourishing result of Coronavirus disease management in South Korea. They did not adopt a total lockdown policy to halt the infection. Reuters reported that the remarkable

44 Ibid., 66-68.

45 The 1945 Constitution of the Republic of Indonesia, Art. 4 (1).

46 Ibid., Art. 6A (1).

47 See Vago, op.cit., 223.

48 Al Jazeera, "Chaos and Hunger Amid India Coronavirus Lockdown", https://www.aljazeera.com/news/2020/03/chaos-hunger-india-coronavirus-lockdown200327094522268.html.

49 Independent, "Why Italy's Coronavirus Death Toll Continues to Spike Despite Lockdown and What UK Can Learn", https://www.independent.co.uk/news/world/europe/italy-coronavirus-death-tolllockdown-uk-self-isolation-social-distancing-a9414581.html. 
strategies worked on their widespread testing, intensive contact tracing, and tracking apps approaches of which the social-distancing policy contained. Recently, after approximately three months of conducting this policy, South Korea announces the fruitful result as well as eases their social distancing policy. 50

At the end of March 2020, Government Regulation No. 21 of 2020 concerning Large-Scale Social Restriction (hereinafter, Government Regulation on Social Restriction) was issued, by which, according to the officers, the balance between economic sustainability and people security is arranged. ${ }^{51}$ Obviously, the Government adopts the Korean policy concerning the Coronavirus outbreak. Later, the Government can tell the people a relatively-successful method conducted by another state or society while applying the rule.

Another lesson-learned can be observed from the way the Government of the Peoples' Republic of China treated its citizens in a momentous Chinese New Year at the time of COVID-19 outbreak. Interestingly, the Chinese government employed nation-wide travel prohibition. It affected a lot of public transportation features, such as railway, bus, flight, and ferry sailings. Although it is a Chinese routine celebration every year, the authorities limited the number of national transportation services in order to support the previous cancellation of the new year celebration. ${ }^{52}$

The Chinese experience of travel ban policy inspired the Government of Indonesia to feature this into the major policy of large-scale social restriction. Ruled in the Ministerial of Transportation Regulation, this ban aims to reduce the possible spread of COVID-19 while the annual homecoming occurs massively. ${ }^{53}$

\subsubsection{Failure to Avoid Frequent Changes}

Despite the state of emergency, the Government of Indonesia admits that the situational approach should be applied to their response to the spread of COVID-19. Among some ministerial regulations, the Minister of Transportation Regulation also observed the factual conditions thoroughly. ${ }^{54}$ For example, the Minister arranged a relaxation of transportation services to which numerous transportation experts say that it is a confusing change of

50 Reuters, "South Korea to Relax Social Distancing Rules Further Starting May 6", https://www.reuters.com/article/us-health-coronavirus-southkorea/south-korea-to-relaxsocial-distancing-rules-further-starting-may-6-idUSKBN22F06C.

51 Tempo (c), "Government Insists Lockdown Not an Option yet", https://en.tempo.co/read/1326376/government-insists-lockdown-not-an-option-yet.

52 Washington Post, "Chinese cities Cancel New Year Celebrations, Travel Ban Widens in Effort To Stop Coronavirus Outbreak", https://www.washingtonpost.com/world/coronavirus-china-wuhanlatest/2020/01/23/2dc947a8-3d45-11ea-afe2-090eb37b60b1_story.html

53 See Regulation of Minister of Transportation No.25 of 2020 concerning Transportation Control During the 1441 AH Annual Homecoming, Art. 1.

54 See the Regulation of Minister of Transportation No.41 of 2020 concerning the Amendment of Regulation of Minister Transportation No.25 of 2020 concerning Transportation Control During the 1441 AH Annual Homecoming, First Consideration. 
policy. ${ }^{55}$ Without any clear and reasonable consideration, the experts' assumptions bear after the government softens their restrictive approach to handle this outbreak. In short, although it was followed by other legal instruments, it is still a debatable change of law.

In fact, this relaxation brought about a huge number of people came to public airports, harbours, and bus stations as well as heading to their hometown. Apart, in spite the government insisted that the health protocols ought to be conformed to the travellers, the police examination of the fake hospital letter case is an essential health security issue. ${ }^{56}$ Apart from those

In a normative sense, the law should be steady in terms of legal certainty. An indicator of steadiness, as depicted by Fuller, is that the lawgivers should avoid frequent changes in the established rule. ${ }^{57}$ It should be done in order to keep the legal substances in steadiness. In a practical sense, the legal certainty helps the legal subjects to determine what they ought to do in accordance with the legal substances. In case of this gradual change, people could expect another change relating to the annual homecoming prohibition. Of course, this drives people to break the mudik ban.

However, a steady law does not resist any change to which a rigid law refers. It is still possible to amend once a fundamental change of circumstance occurs. Similarly, the unimportant change would never be considered by the lawmakers to change a well-established law.

This steadiness, of course, is corresponding to Max Weber's assumption of the 'calculability of rules' as follows:

But for modern bureaucracy, the element of 'calculability of its rules' has really been of decisive significance. The nature of modern civilization, especially its technical-economic substructures, requires this 'calculability' of consequences. Fully developed bureaucracy operates in a special sense sine ira ac studio. 58

In this discussion, what Weber thinks of "calculability of its rules" relates to the circumstances in which the law can perform properly. In a concept of autonomous law, Philippe Nonet and Philip Selznick contend that "law is elevated 'above' politics". 59 It means that, once the political

55 Jakarta Post (c), "Experts Slam Govt for 'Inconsistent, Poor' Covid-19 Policies after Transport Relaxation”, https://www.thejakartapost.com/news/2020/05/08/experts-slamgovt-for-inconsistent-poor-covid-19-policies-after-transport-relaxation.html.

56 Jakarta Post (d), "Bali Police Arrest Seven for Allegedly Selling COVID-19 Travel Permits at Gilimanuk Port", https://www.thejakartapost.com/news/2020/05/16/balipolice-arrest-seven-for-allegedly-selling-covid-19-travel-permits-at-gilimanuk-port.html.

57 See Vago, op.cit., 223. See also Fuller, loc.cit.

58 Sine ira ac studio is defined by Weber as "wihout bias or favour". Max Weber, "Rational and Irrational Administration of Justice", in Sociology of Law: Selected Readings, edited by Vilhelm Aubert (New York: Penguin Books Ltd., 1977), 155.

59 Philippe Nonet and Philip Selznick, Law and Society in Transition: Toward Responsive Law (New Brunswick: Transaction Publishers, 2009), 57. 
mechanism meets the consensus among the politicians, the law is not a part of political (and other non-legal) controversy anymore.

With regards to government's non-legal considerations, like the negative growth of the national economy, to which the readjustment of mudik prohibition accords, this paper argues that those considerations are out of so-called "the fundamental change of circumstances". Therefore, the readjustment, or relaxation, of mudik ban is not essentially needed anymore. It, of course, should be assumed that the government must take into account the policy as well as its positive and negative impacts prior to the enactment of policy.

Later on, frequent changes of an enacted law shall destruct the integrity of the law. Law becomes less legitimate because its norms can be readjusted without any legal considerations. Moreover, this precedence can justify the lawmakers' incapability of making a well-arranged law.

\subsubsection{Lack of 'Legally-accepted' Punishments}

Punishment is an instrument to enforce the law in the form of physical or non-physical sanctions. Max Weber conceives the existence of punishment, as follows:

A normative order, in other words, must always be accompanied by mechanisms and systems of control that secure obedience through norm enforcement. Such systems of control range from very informal responses ... to highly formalised systems of enforcement of law by police institutions and system of surveillance and punishment. 60

Magnis-Suseno argues that, due to its legitimacy, the government has the right to determine punishments subjected to the violators. Moreover, the law, with its punishments, is not a mere suggestion, but it takes everyone's absolute obedience. ${ }^{61}$

Generally, as determined by Article 93 of Law No. 6 of 2018 concerning Health Quarantine, a person who offends the health quarantine policy (Law on Health Quarantine), in which large-scale social restriction includes, shall be stipulated to a criminal sanction of 1-year imprisonment and a fine of 100 million rupiahs. ${ }^{62}$ The provision determines that: (i) the violation is regarded as a crime and (ii) the offender shall be sentenced to the criminal sanction(s).

It is obvious that regulations that derive from Law on Health Quarantine, such as Government Regulation on Social Restriction Regulation and Transportation Minister Regulation on Mudik Control indicate uncertainty in punishing the offenders. It leads the Minister of Internal Affair to instruct the heads of regional governments to utilise social

\footnotetext{
60 Deflem, op.cit., 227.

61 Magnis-Suseno, op.cit., 206.

62 Law No.6 of 2018 concerning Health Quarantine, Art. 93.
} 
punishment mechanisms. ${ }^{63}$ For example, the Governor of Special Capital Region of Jakarta enacted a regulation that implements social punishments to be imposed to any violation of the social restriction. ${ }^{64}$

Unlike the sanctions for the violators against social restrictions above, it is still confounding to determine the punishment applied for the mudik ban offenders. These comparable pictures illustrate how the government establishes a legal regime of large-scale social restrictions in an ad-hoc readjustment.

It also corresponds to the fact supplied by I Made Arya Utama. He depicts the facts regarding a large number of violations against the rules. ${ }^{65}$ Here, the absence of "legally-accepted" leads the people to assume that the officials do not consider Covid-19 countermeasures action as serious legal instrument.

Janice Nadler argues that the existence of legal sanctions addressing coercive power, whether it is criminal, civil, or administrative sanctions strengthens the legal system. In practical sense, Nadler shows that "to avoid civil liability or administrative sanctions, people are forced to refrain from doing things they might prefer to do".66

Similarly, Soekanto expresses his ideas of negative sanctions and legal certainty by arguing that the application of sanctions should be covered by legal certainty. If the legal certainty is well-improved, law will have more integrity. Thus, the negative sanctions ${ }^{67}$ will be more powerful to prevent the increasing number of crimes and recidivism. 68 The absence of so-called punishment reduces legal certainty. In a practical sense, if a sanction for a thief was not legally determined, it would be a trigger for a good citizen to violate the norm due to the powerless law.

\subsubsection{An Ignorance to Consider the Social Contexts}

This part discusses the theoretical basis of the social phenomenon in which, in spite of the travel ban, people still try to return to their hometown as well as violate the ban. This paper proposes two essential considerations

63 Sindonews, "Mendagri: Pelanggar PSBB Wajib Diberikan Sanksi Sosial", https://nasional.sindonews.com/read/26495/15/mendagri-pelanggar-psbb-wajibdiberikan-sanksi-sosial-1589321112

${ }^{64}$ See Article 4 (1) of the Regulation of Governor of Special Capital Region of Jakarta Province No. 41 of 2020 concerning the Imposition of Sanctions for Violations of the Implementation of Large-Scale Social Restrictions in Handling COVID-19 in the Special Capital Region of Jakarta Province, that determines individuals who committing an offense against the health protocols would be sentenced with community service sanction.

65 I Made Arya Utama, "Do Indonesia Law and Policies on Covid-19 Countermeasures Action Reflect Legality?", Udayana Journal of Law and Culture 4, no. 2 (2020): 223.

66 Janice Nadler, "Expressive Law, Social Norms, and Social Groups", Law and Social Inquiry 42, no. 1 (2017): 61.

67 "Negative sanctions are penalties imposed on those who violate norms". See Vago, op.cit., 136.

68 Soerjono Soekanto (b), Faktor-faktor yang Mempengaruhi Penegakan Hukum (Jakarta: Rajawali Pers, 2014), 43. 
ignored by lawmakers. Firstly, the annual homecoming can be described as a social value. Subsequently, the discussion on the redefinition of social solidarity in Indonesia would be an integrative part to underline the alienation of social contexts from the lawmaking process. Social value refers to "an element of 'conformity' to the established order". 69 This, of course, is different from how the legal scholars observe legal norms. Donald Black, as cited by Soekanto, obviously clarifies the difference: "from a sociological point of view, law is not what lawyers regard as binding or obligatory precepts, but rather, for example, the observable dispositions of judges, policemen, prosecutors, or administrative officials". ${ }^{70}$

Koentjaraningrat illustrates that the social value (in a specific term of cultural value) determines as well as controls everyone's behaviour within the society. Afterward, the value becomes a pattern of the social system to which all social members' interaction pertains. ${ }^{71}$

Irianto describes an interesting analysis of how this annual exodus exists from the perspective of a system of value. He develops an about using 'dalem', a Javanese word. 'Dalem' means 'me' as well as refers to 'home'. Furthermore, the latter covers not only the building of a house but also the identity of Javanese. In-depth, this is a symbol of their origins, their villages. ${ }^{72}$

Accordingly, Bahtiar Effendy supplies a supplemental argumentation that mudik relates to the socio-cultural perspective. For example, the tradition of forgiveness (halal bi halal) among the Indonesian Muslims in the moment of lebaran (Eid al Fitr). He, also discloses that "the surge of willingness to forgive renews and strengthens social bonds and the mass homecoming reenergizes cultures and family ties". ${ }^{73}$ To summarise the points respectively described by Irianto and Effendy, this annual homecoming could be marked as a ritual of reconnecting, remembering, and recharging. ${ }^{74}$

Prior to Indonesian independence, Mohammad Hatta stated that collectivism is an ideal of Indonesian people. Based on the collectivism, Indonesian people possessed their communal value on which people work together (gotong royong). ${ }^{75}$ Djokosoetono classifies this value into two

\footnotetext{
${ }^{69}$ Denis Sekiwu and M.M. Botha, "Values for a Social Development in the Context of Globalisation: Analysing the Role of the Ugandan School", Global Journal of Human-Social Science: Linguistics and Education 14, no. 4 (2014): 28.

70 Soerjono Soekanto and Purnadi Purbatjaraka, Sendi-Sendi Ilmu Hukum dan Tata Hukum (Bandung: PT Citra Aditya Bakti, 1983), 13.

71 Koentjaraningrat, Kebudayaan, Mentalitas, dan Pembangunan (Jakarta: PT Gramedia Pustaka Utama, 2015), 7.

72 Irianto, loc.cit.

73 Bahtiar Effendy, Insight: Essays on Islam and Public Affairs (Bekasi: PT Penjuru Ilmu Sejati, 2017), 18.

74 Vissia Ita Yulianto, "Is the Past Another Country? A Case Study of Rural-urban Affinity on Mudik Lebaran in Central Java", Journal of Social Sciences and Humanity 4 (2011): 50.

75 Mohammad Hatta, "Ekonomi Indonesia di Masa Datang", in Satu Abad Bung Hatta, edited by Sri-Edi Swasono and Fauzie Ridjal (Jakarta: Penerbit Universitas Indonesia, 2006), 5-6.
} 
solidarity types to which gotong royong belongs. The first is solidarismus or onderling hulpbetoon on which people work together concerning their public interest. Besides, Djokosoetono mentions mutualismus or wederkerig hulpbetoon on which anyone helps others to get indirect help from others. ${ }^{76}$

In relation to the classification, Koentjaraningrat, in a narrower sense, views gotong royong corresponds to mutualismus. Situationally, this value is generated and developed at villages. He describes that the origin of this communal work was taken from farming activities. Once a farmer helped other farmers to reap corns, it would be an advantage for him to invite his comrades to do the same for his crops. ${ }^{77}$

This circumstance occurred in a homogenous society in which each member had similarities of habits, ideas, and attitudes. 78 Thus, every member of society interdepended upon an agrarian life. In Durkheim words, it was a mechanic society. 79

Theoretically, this mechanic society has been transformed into organic solidarity which a modern society conforms to. Here, money occupies collective conscience as well as substitutes the use of mutualismus like it was. In rural areas, a farmer who works at his neighbour's crops earns money. ${ }^{80}$ In a broader sense, this transformation also covers a lot of social dimensions, such as industrialisation to which dehumanisation and alienation are addressed.

In a relation between industrialisation and social values, Nurcholis Madjid categorises social values into formal value and informal value (or sub-terranean values). The former is established upon industrial relations, while the latter covers people's life in their leisure time. Essentially, the first value is represented in people's professional life in which they gain material objects, such as money. Subsequentially, the material objects they obtain will be allocated to their leisure time. ${ }^{81}$ For instance, after their exhausting workdays in the city, people spent their leisure time in a moment of Eid al Fitr. ${ }^{82}$

The existence of subterranean values, like spending their leisure time at hometown, contradicts the individualism of modern society to which those who live in a city are identical. This indication, captured by Irianto, showing that primordialism exists in modern society. Further, he assumes that primordialism grows in Mondial environment in major cities. ${ }^{83}$

Although the population is not completely disclosed, the existence of the so-called "reserve labour army" could partially explain the paradox. In

76 Djokosoetono, Hukum Tata Negara (Jakarta: In-Hill-Co, 2006), 141-142.

${ }^{77}$ Koentjaraningrat, op.cit., 63.

78 See Vago, op.cit., 39.

79 Ibid.

80 Koentjaraningrat, op.cit., 64.

81 Nurcholis Madjid, Islam, Kemodernan, dan Keindonesiaan, (Bandung: Penerbit Mizan, 2013), 159.

82 Muskinul Fuad describes that people do not only celebrate the holy day, they also perfom a lot of rituals, such as halal bihalal and cemetery visit. See Fuad, op. cit., 109

83 Irianto, loc.cit. 
Jakarta, besides the full-employed, industries also recruit a huge number of the reserves to underpaid and poverty must be addressed. ${ }^{84}$ While they are in their leisure time, the reserves face a culdesac to stay on in the city. Further, it drives this social class to leave the city and join in this mass exodus. Jan Breman emphasises the situation as follows:

The labour market of the informal sector is highly fragmented; those who are laid off in their branch of activity have no alternative but to go back 'home', because staying on in the city without earnings is next to impossible. But returning to their place of origin is not a straightforward option, given the lack of space in the rural economy. Nevertheless, my informants do not simply lay the blame for their predicament on the economic meltdown. From the perspective of the world's underclasses, what looks like a conjunctural crisis is actually a structural one, the absence of regular and decent employment. ${ }^{85}$

From another perspective, rituals could be an add-on to redefine social solidarity in Indonesia. Here, due to its routine, annual homecoming could be mentioned as a ritual. Previously, Durkheim assumes that only traditional tribes perform the rituals. However, Farsijana Adeney-Risakotta criticises a common conception of rituals to which, in Durkheim's assumption, only traditional societies are identical. For Adeney-Risakotta, ritual does not only cover religious matters, but also social, cultural, and political contexts. As well, the ritual is a social phenomenon of both traditional and modern societies that Durkheim categorises into. ${ }^{86}$

\section{CONCLUSION}

Governments currently use the law to change the society on two approaches: direct change and indirect change. Since it is a planned change, the lawmakers should pay attention to the benefits and weaknesses of law in changing society. The benefits stand upon the legitimate institutions by which law is enacted, the binding force of law, and the legal sanctions. However, it also possesses limitations which several conditions accords comply with, such as comprehensive and systematic conflict settlement, reference or benchmark, the law enforcement, and use of punishment.

In regard to the advantages and conditions in which law could successfully change the society, this paper analyses the prohibition of homecoming from such aspects. First, the regulation has been established by a legitimate authority. Second, the contents determined by the rule rely upon a "best-practice" reference. Third, it would be a shortcoming after the government changes the law without any sufficient reason frequently. The

84 Arif Novianto, “Memperbesar Tentara Cadangan Pekerja: 'Bonus Demografi' dan Ekonomi Politik Negara Neoliberal di Indonesia", Kawistara 7, no. 2 (2017): 191.

85 Jan Breman, "Myth of the Global Safety Net", New Left Review 59 (2009): 34

86 Laila Kholid Alfirdaus, Eric Hiariej, and Farsijana Adeney-Risakotta, "Theories of Social Solidarity in the Situations of (Natural) Disasters", Politika 6, no. 11 (2015). 
last, the uncertainty of sanction impositions contributes to the reduction of legal certainty.

Besides, the paper also captures two social contexts to which the government does not pay attention. Firstly, mudik is a tradition to which several social values correspond. Later on, the tradition benefits society in the way of strengthening family ties and social bonds. Secondly, another ignorance is regarding the essence of social solidarity in Indonesia. The government cannot directly assume that a traditional society must leave traditional values prior to transforming to the modern one. The picture of the society of Indonesia illustrates that traditional values, such as annual homecoming as a ritual, exist among the modernisation and industrialisation of society.

\section{BIBLIOGRAPHY \\ Book}

Bix, Brian H. A Dictionary of Legal Theory. Oxford University Press, 2009.

Budiardjo, Miriam. Dasar-Dasar Ilmu Politik. Jakarta: PT Gramedia Pustaka Utama, 2010.

Deflem, Mathieu. Sociology of Law: Visions of a Scholarly Tradition. New York: Cambridge University Press, 2008.

Djokosoetono. Hukum Tata Negara. Jakarta: In-Hill-Co, 2006.

Effendy, Bahtiar. Insight: Essays on Islam and Public Affairs. Bekasi: PT Penjuru Ilmu Sejati, 2017.

Fuller, Lon F. The Morality of Law. New Haven: Yale University Press, 1969.

Koentjaraningrat. Kebudayaan, Mentalitas, dan Pembangunan. Jakarta: PT Gramedia Pustaka Utama, 2015.

Madjid, Nurcholis. Islam, Kemodernan, dan Keindonesiaan. Bandung: Penerbit Mizan, 2013.

Magnis-Suseno, Franz. Etika Politik: Prinsip Moral Dasar Kenegaraan Modern. Jakarta: PT Gramedia Pustaka Utama, 2016.

Nonet, Philippe, and Philip Selznick. Law and Society in Transition: Toward Responsive Law. New Brunswick: Transaction Publishers, 2009.

Sidharta, Bernard Arief. Refleksi tentang Struktur Ilmu Hukum: Sebuah Penelitian tentang Fundasi Kefilsafatan dan Sifat Keilmuan Hukum sebagai Landasan Pengembangan Ilmu Hukum Nasional. Bandung: CV Mandar Maju, 2009.

Soekanto, Soerjono. Faktor-faktor yang Mempengaruhi Penegakan Hukum. Jakarta: Rajawali Pers, 2014.

Pokok-pokok Sosiologi Hukum. Jakarta: PT RajaGrafindo Persada, 2006.

Soekanto, Soerjono, and Purnadi Purbatjaraka. Sendi-Sendi Ilmu Hukum dan Tata Hukum. Bandung: PT Citra Aditya Bakti, 1983.

Vago, Steven. Law and Society. New Jersey: Prentice-Hall, Inc., 1991.

Van Apeldoorn, L.J. Pengantar Ilmu Hukum [Inleiding tot de Studie van het Nederlandsche Recht]. Translated by Oetarid Sadino. Jakarta: Pradnya Paramita, 2011. 


\section{Chapter in an Edited Book}

Dror, Yehezkel. "Law and Social Change". In Sociology of Law: Selected Readings, edited by Vilhelm Aubert, 90-99. New York: Penguin Books Ltd., 1977.

Hatta, Mohammad. "Ekonomi Indonesia di Masa Datang". In Satu Abad Bung Hatta, edited by Sri-Edi Swasono and Fauzie Ridjal, 3-17. Jakarta: Penerbit Universitas Indonesia, 2006.

Weber, Max. "Rational and Irrational Administration of Justice". In Sociology of Law: Selected Readings, edited by Vilhelm Aubert, 153-160. New York: Penguin Books Ltd., 1977.

\section{Journal Article}

Alfirdaus, Laila Kholid, Eric Hiariej, and Farsijana Adeney-Risakotta, "Theories of Social Solidarity in the Situations of (Natural) Disasters", Politika 6, no. 11 (2015). https://doi.org/10.14710/politika. 6.1.2015.44-70

Breman, Jan. "Myth of the Global Safety Net". New Left Review 59(2009): 29-36.

Fuad, Muskinul. "Makna Hidup Di Bauk Tradisi Mudik Lebaran (Studi Fenomenologi Atas Pengalaman Pemudik Dalam Merayakan Idul Fitri di Kampung Halaman)." KOMUNIKA: Jurnal Dakwah dan Komunikasi 5, no. 1 (2011): 107-123. https://doi.org/10.24090/komunika.v5i1.774

Irianto, Agus Maladi. "Mudik dan Keretakan Budaya". Humanika 15, no.2 (2012). https://doi.org/10.14710/humanika.15.9.

Leeuw, Frans L. "Empirical Legal Research: The Gap between Facts and Values and Legal Academic Training". Utrecht Law Review 11, no. 2 (2015): 19-33. http://doi.org/10.18352/ulr.315

Nadler, Janice. "Expressive Law, Social Norms, and Social Groups". Law and Social Inquiry 42, no.1 (2017): 60-75. https://doi.org/10.1111/ $\underline{1 \text { si. } 12279}$

Novianto, Arif. 'Memperbesar Tentara Cadangan Pekerja: 'Bonus Demografi' dan Ekonomi Politik Negara Neoliberal di Indonesia”. Kawistara 7, no. 2 (2017): 187-200. https://doi.org/10.22146/kawistara.18834

Sekiwu, Denis, and M.M. Botha, "Values for a Social Development in the Context of Globalisation: Analysing the Role of the Ugandan School". Global Journal of Human-Social Science: Linguistics and Education 14, no. 4 (2014): 26-36.

Utama, I Made Arya. "Do Indonesia Law and Policies on Covid-19 Countermeasures Action Reflect Legality?". Udayana Journal of Law and Culture 4, no. 2 (2020): 211-228. https://doi.org/10.24843/UJLC.2020.v04.i02.p05

Yulianto, Vissia Ita. "Is the Past Another Country? A Case Study of Ruralurban Affinity on Mudik Lebaran in Central Java". Journal of Social Sciences and Humanity 4 (2011): 49-66. http://dx.doi.org/10.14203/jissh.v4i0.118 


\section{Legal Documents of the Republic of Indonesia}

The 1945 Constitution of the Republic of Indonesia.

Law No. 6 of 2018 concerning Health Quarantine. State Gazette of 2018 No. 128, Supplement to State Gazette No. 6236.

Government Regulation on Large-scale Social Restriction in the Effort to Handle COVID-19. Government Regulation No.21 of 2020, State Gazette of 2020 No. 91, Supplement to State Gazette No. 6487.

Regulation of Minister of Health on Guidelines of Large-scale Social Restriction. Regulation of Minister of Health No. 9 of 2020, Official Gazette of 2020 No.326.

Regulation of Minister of Transportation No.25 of 2020 concerning Control During the 1441 AH Annual Homecoming. Official Gazette of 2020 No. 405.

Regulation of Minister of Transportation No.41 of 2020 concerning the Amendment of Regulation of Minister Transportation No.25 of 2020 concerning Transportation Control During the 1441 AH Annual Homecoming. Official Gazzette of 2020 No.587.

Regulation of Governor of Special Capital Region of Jakarta Province No. 41 of 2020 concerning the Imposition of Sanctions for Violations of the Implementation of Large-Scale Social Restrictions in Handling COVID19 in the Special Capital Region of Jakarta Province

\section{Website Content}

Al Jazeera. "Chaos and Hunger Amid India Coronavirus Lockdown". https://www.aljazeera.com/news/2020/03/chaos-hunger-indiacoronavirus-lockdown-200327094522268.html.

Cabinet Secretariat of the Republic of Indonesia. "Gov't Revises National Holiday, Collective Leave 2020". https://setkab.go.id/en/govt-revisesnational-holiday-collective-leave-2020/

CNBC Indonesia. "Ada Corona, 1,3 Juta Orang Tetap Ngotot Mudik di Jabodetabek.

https://www.cnbcindonesia.com/news/20200414125207-4-

151775/ada-corona-13-juta-orang-tetap-ngotot-mudik-dijabodetabek.

Historia. "Lebaran tanpa Mudik di Awal Republik". https:/ / historia.id/militer/articles/lebaran-tanpa-mudik-di-awalrepublik-vX1Or.

$$
\text { "Mudik Tahun 1960-an". }
$$

https: / / historia.id/urban/articles/ mudik-tahun-1960-an-6k4pR.

Independent. "Why Italy's Coronavirus Death Toll Continues to Spike Despite Lockdown and What the UK Can Learn". https://www.independent.co.uk/news/world/europe/italycoronavirus-death-toll-lockdown-uk-self-isolation-social-distancinga9414581.html.

Jakarta Post. "Bali Police Arrest Seven for Allegedly Selling COVID-19 Travel Permits at Gilimanuk Port". https: / /www.thejakartapost.com/news/2020/05/16/bali-policearrest-seven-for-allegedly-selling-covid-19-travel-permits-atgilimanuk-port.html. 
. "Experts Slam Govt for 'Inconsistent, Poor' Covid-19 Policies after Transport Relaxation". https: / / www.thejakartapost.com/news/2020/05/08/experts-slamgovt-for-inconsistent-poor-covid-19-policies-after-transportrelaxation.html.

. "Government to Allow Public Transportation to Operate but Still bans 'Mudik"'. https://www.thejakartapost.com/news/2020/05/06/government-toallow-public-transportation-to-operate-but-still-bans-mudik.html. . "Public Transportation Use in Greater Jakarta Plummets during Pandemic: BPTJ". https: / / www.thejakartapost.com/news/2020/04/20/publictransportation-use-in-greater-jakarta-plummets-during-covid-19pandemic-bptj.html.

Reuters. "South Korea to Relax Social Distancing Rules Further Starting May 6". https://www.reuters.com/article/us-health-coronavirussouthkorea/south-korea-to-relax-social-distancing-rules-furtherstarting-may-6-idUSKBN22F06C.

Sindonews. "Mendagri: Pelanggar PSBB Wajib Diberikan Sanksi Sosial". https: / / nasional.sindonews.com/read/26495/15/mendagripelanggar-psbb-wajib-diberikan-sanksi-sosial-1589321112.

Tempo. "Government Insists Lockdown Not an Option yet". https://en.tempo.co/read/1326376/government-insists-lockdownnot-an-option-yetTempo. "MRT Jakarta Closes Two More Stations". https://en.tempo.co/read/1334459/mrt-jakarta-closes-two-morestations.

. "Polisi Sebut Ada Orang yang Ngumpet di Truk Molen agar Bisa Mudik". https://nasional.tempo.co/read/1339435/polisi-sebut-adaorang-yang-ngumpet-di-truk-molen-agar-bisa-mudik

United States Department of Education. "Impact of the Civil Rights Laws". https: / / www2.ed.gov/about/offices/list/ocr/docs/impact.html.

Washington Post. "Chinese cities Cancel New Year Celebrations, Travel Ban Widens in Effort To Stop Coronavirus Outbreak". https://www.washingtonpost.com/world/coronavirus-china-wuhanlatest/2020/01/23/2dc947a8-3d45-11ea-afe2090eb37b60b1_story.html 